\title{
Computerized geochemical modeling of burial diagenesis of the Eocene turbidite reservoir elements: Urucutuca Formation, Espírito Santo Basin, southeastern Brazil passive margin
}

\author{
Marcos Antonio Klunk ${ }^{1}$, Sudipta Dasgupta ${ }^{2^{*}}$ and Rommulo Vieira Conceição ${ }^{1}$
}

\begin{abstract}
The computerized geochemical modeling, a useful tool to understand the diagenetic processes influencing the quality of hydrocarbon reservoirs, is performed by using different modules of computer codes based on the thermodynamic and chemical kinetic principles and their associated parameters. As observed in the reservoir lithofacies deposited from the marine sediment-gravity flows, a case study of diagenesis is presented here from the Espírito Santo Basin in southeastern Brazil. The study uses the Geochemist's Workbench (GWB $\left.{ }^{\mathrm{TM}}\right)$, PHREEQC ${ }^{\mathrm{TM}}$ and TOUGHREACT ${ }^{T M}$ computation packages. The comparison of performances of these packages demonstrates the convergence of results from the software-based geochemical modeling with the petrographic observation of dissolution, albitization, kaolinization, and the precipitation of calcite and dolomite. Moreover, with limited data points, e.g., the sedimentary petrographic data acquired from limited number of boreholes, the computer simulation establishes itself to be a powerful quantitative method estimating the degree and type of diagenetic alteration of turbidite reservoir bodies in contact with a source of saline-water influx associated with salt tectonics. Therefore, using the limited petrographic data points, the geochemical computer-simulation method can even be utilized and extrapolated for areas where similar geological context is interpreted but no borehole data are available. Hence, porosity of turbidite reservoir lithofacies can be predicted in relation to the spatial distribution of dissolution, kaolinization, and albitization of feldspars and authigenic carbonate precipitation.
\end{abstract}

Keywords: Sandstone diagenesis, Computerized diagenetic modeling, Turbidite reservoir, GWB, PHREEQC, TOUGHREACT

\section{Introduction}

\subsection{Computerized geochemical modeling}

Over the last few decades, investigators in the hydrocarbon exploration-, development-, and production-related sector have been trying to address the increasing complexity of reservoir formations and the consequent uncertainty which also include post-depositional diagenetic changes taking place within the reservoir architectural elements. The geochemical transport- and reaction-modeling

\footnotetext{
* Correspondence: klunkdasgupta@gmail.com

${ }^{2}$ Department of Earth Sciences, Indian Institute of Technology (IIT) Bombay,

Mumbai, India

Full list of author information is available at the end of the article
}

technique is used to evaluate the progressive development and spatial dispersal of diagenetic processes for characterizing and predicting reservoir quality of formations (Meshri and Ortoleva 1990; Genthon, Schott and Dandurand 1997; Taylor et al. 2010; Klunk et al. 2015; Yang et al. 2017). To continuously develop and to apply new scientific techniques are vital in addressing the diagenesis-related reservoir uncertainties. Computational geochemical modeling is one of such geoscientific approaches. The technique uses computer-based codes involving the thermodynamic and chemical kinetic principles and parameters. There are several geochemical modeling methods available with their corresponding trademarked software modules equipped 
with their own computational codes. Due to the complex multivariate nature of the simulation parameters as well as their interrelationship, each code and/or step must be used with diligence. Moreover, both the precondition and derivatives of each step must be corroborated with the geological and petrological context in order to accurately simulate the progressive occurrence of diagenetic environments.

Development of the numerical codes for computerized geochemical modeling has been the objective of several research organizations dedicated to the effective petroleum exploitation and sedimentary petrology around the world. An important prerequisite to be considered before constructing a geochemical model is that the results must be calibrated after simulation with a reference set of data derived from, for example, at least a borehole (i.e., from sedimentological and formation-water data analyzed from conventional cores, cuttings, and sidewall cores) or from an analog outcrop that represents the geological context of the computer model. This allows testing the validity and reliability of the codes and increases confidence in employing an individual geochemical computer-modeling module elsewhere in the same geological context where well data are lacking. Additionally, once a numerical method is defined and calibrated for a specific sedimentological and stratigraphic context, it is also possible to carry out simulations by modifying variables or parameters to test the sensitivity of the model by considering various geological scenarios which arise from different seismic-stratigraphic interpretations (with or without additional borehole calibration points).

The "scenario" for a geochemical modeling case is considered to be the set of parameters of the reservoir architectural element(s), e.g., mineralogical composition (expressed as volumetric percentages or modal values), burial history, the temporal sequence of mineral precipitation/crystallization, interstitial fluid, and so forth, that define the sedimentary-petrological evolution within a diagenetic regime.

\subsection{Objectives and method/workflow for computerized geochemical modeling}

In this study, we reproduced the diagenetic reaction series in the reservoirs from the Espírito Santo Basin (ESB) in southeastern Brazil. The ESB is mainly an offshore basin (Fig. 1). The Tertiary reservoir horizons are the deposits of sandy sediment-gravity flows (Fig. 2) and are hereafter referred to simply as the turbidites or turbidite sandstones. The petrographic analysis of these turbidites suggests a diagenetic history being divided into 4 stages: the marine eodiagenesis, the meteoric eodiagenesis, the compactional mesodiagenesis, and the thermobaric mesodiagenesis (sensu Galloway 1984; Worden and Burley 2003).

To model the diagenesis of these reservoirs, we made use of the softwares Geochemist's Workbench $\left.\left(\mathrm{GWB}^{\mathrm{m}}\right)^{\mathrm{N}}\right)$,

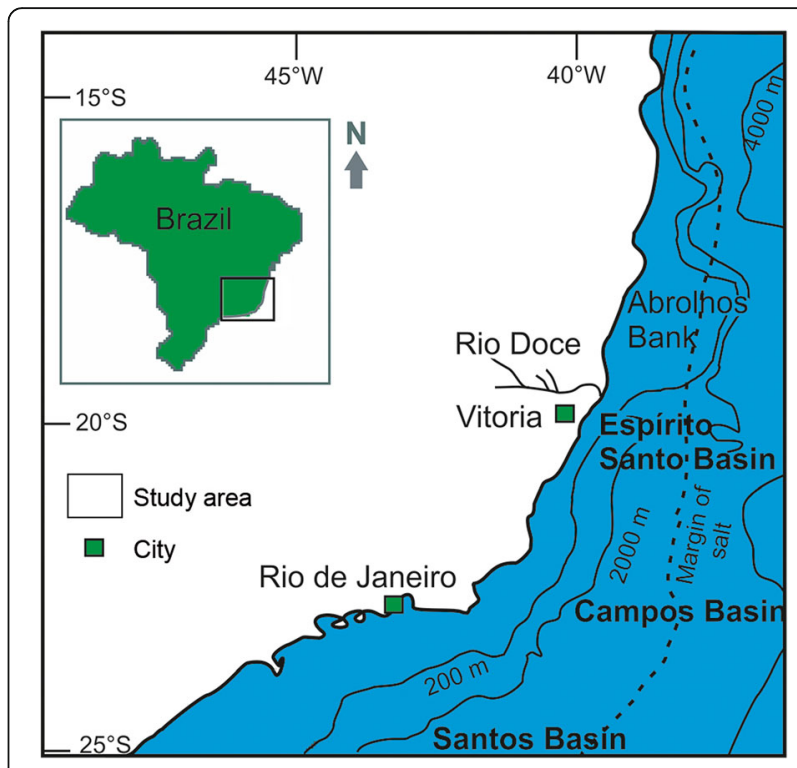

Fig. 1 Location map of the offshore Espírito Santo Basin with a map of Brazil in the inset. The contours show water depth

PHREEQC ${ }^{\mathrm{Tm}}$, and TOUGHREACT ${ }^{\mathrm{Tm}}$. Their source codes are based on advection-dispersion/diffusion models, thereby, providing the thermodynamic and kinetic parameters in order to simulate each diagenetic reaction. All the 3 software platforms were used in the batch mode (i.e., models that do not consider the mass transfer out of the system and refer only to the geochemical reactions) (Bethke 2002). The GWB $^{\text {mix }}$ and TOUGHREACT ${ }^{\mathrm{Tn}}$ were also separately used for the dynamic condition models that consider the mass-transfer processes in one-dimensional (1-D) flow direction with respect to time and distance from the reaction front (Bethke 2002; Pruess 1991; Xu and Pruess 1998).

The results (i.e., the models, also referred to here as GM) of the computerized geochemical modeling have been compared (and/or ground-truthed) with the petrographic data as observed in thin sections (TS) described by de Oliveira et al. (2018). The available petrographic data is a restricted and confidential proprietary of the operating company Petróleo Brasileiro S.A. (Petrobras). Therefore, in order to demonstrate the textural and mineralogical context at the microscopic scale, the authors have constructed the schematic photomicrographic diagrams (hereafter referred to as the implicit photomicrographs) using the computer drafting software CorelDraw ${ }^{\text {max }}$. The implicit photomicrographs represent the textural fabric and the mineralogical contents of the original thin-section photomicrographs and are presented in this study (Fig. 3a-h). The modal values of the mineral constituents and the framework-matrix-cement relationship remain unchanged.

With implications in reservoir modelling and petroleum-system modeling (or basin modeling), the ultimate objectives of geochemical modeling are to demonstrate: 


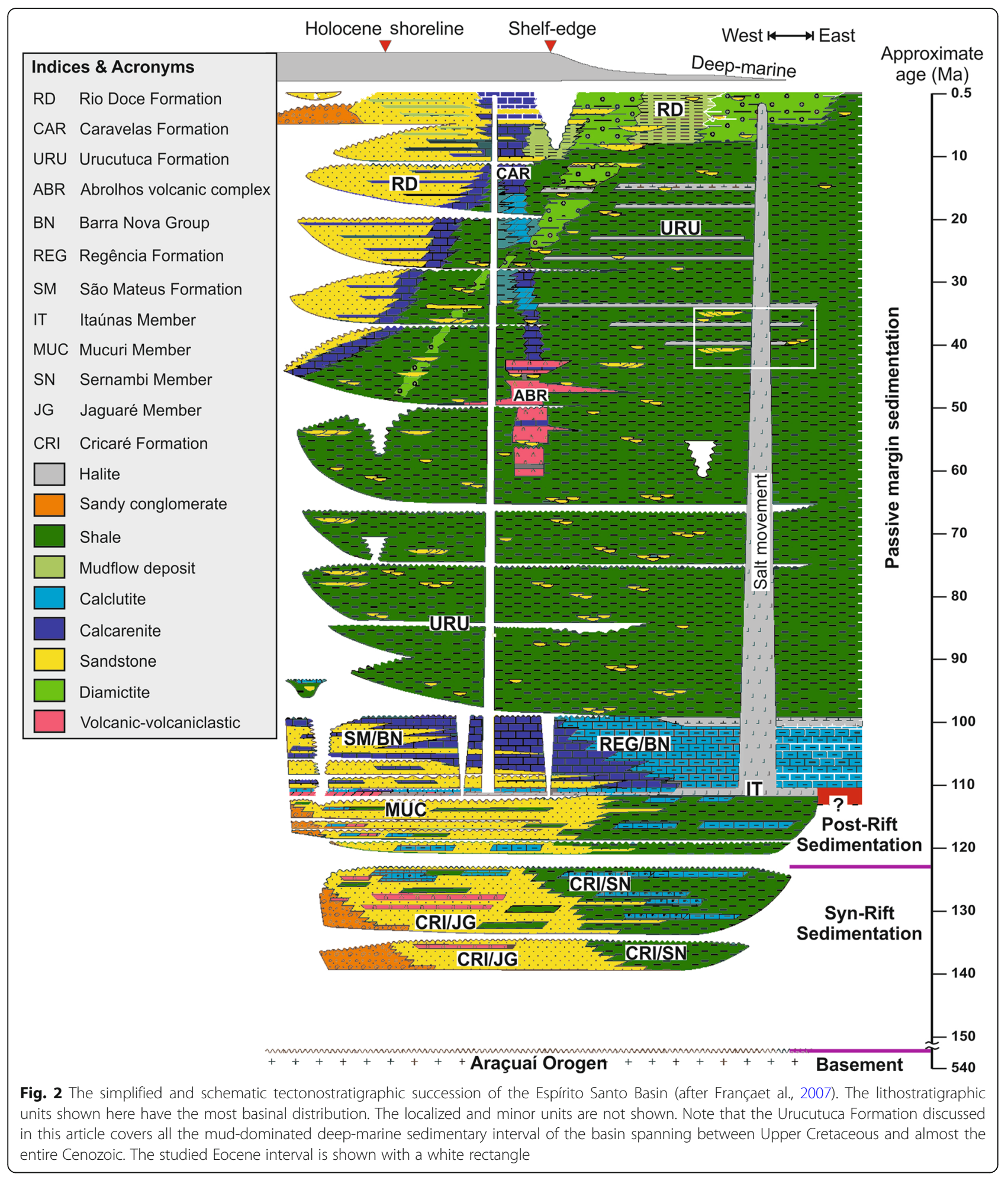

(1) The sequential stages of diagenetic changes (e.g., the alteration processes of detrital feldspars, i.e., albitization and kaolinization, the quartz overgrowth cementation, and the authigenic growth of calcite and dolomite in the pore spaces of the reservoir); and (2) The time-window variations with distances from the reaction front to achieve the chemical equilibria within the analogous stratigraphic contexts. The evaluation of three-dimensional spatial variation of petrophysical properties due to diagenesis is not the intent of this article. 

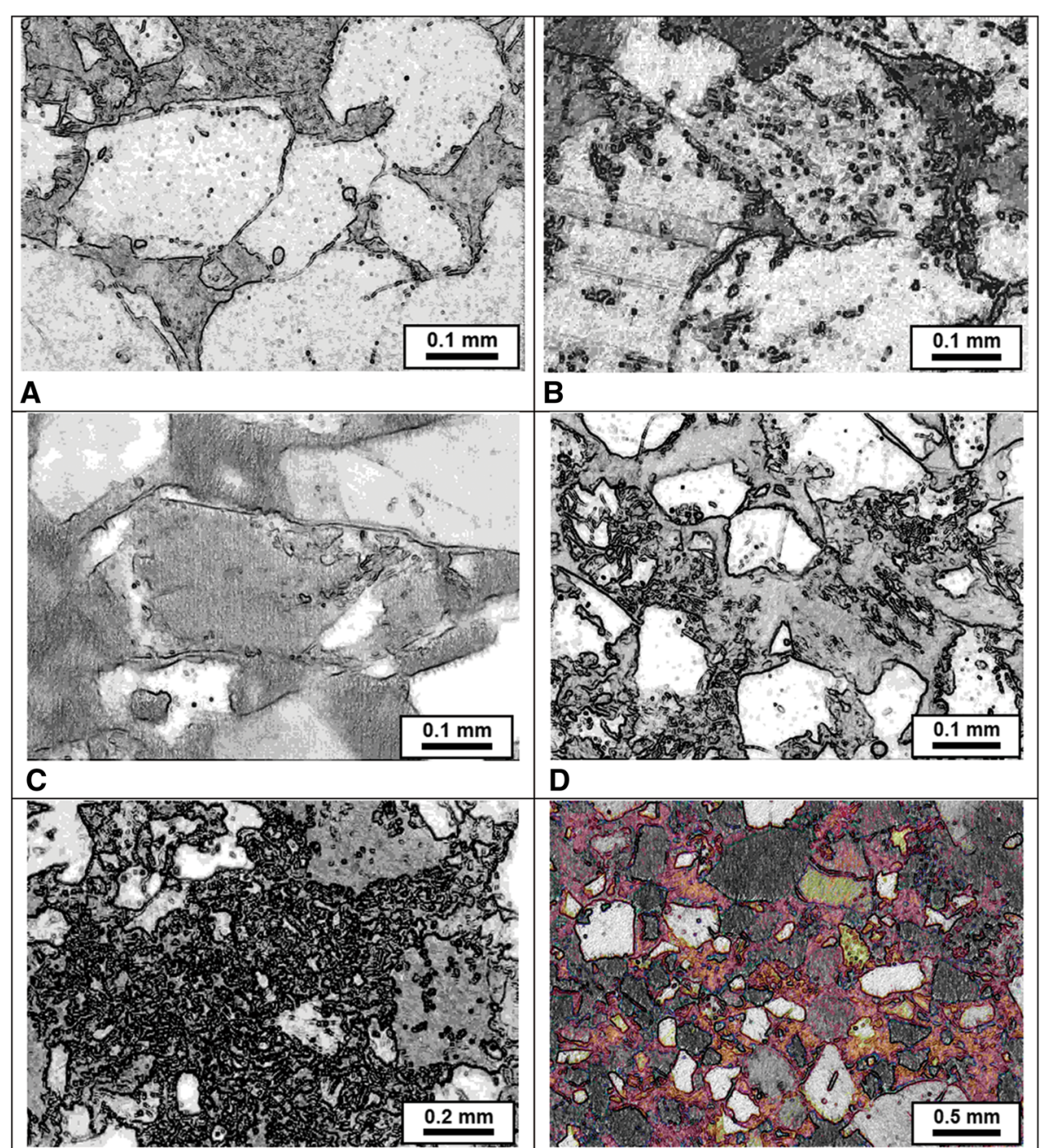

$\mathbf{E}$
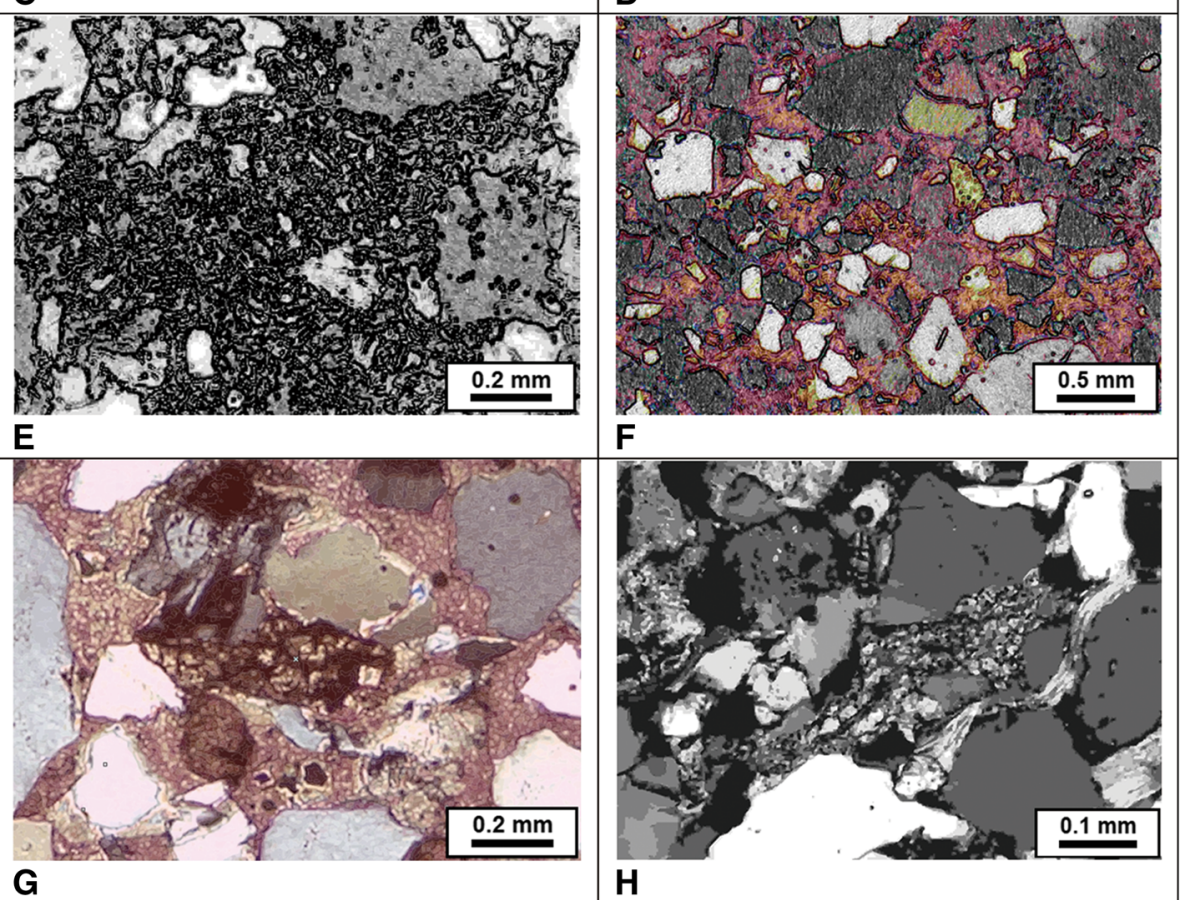

Fig. 3 Digital implicit photomicrographs (see text for explanation) resembling and representing the mineralogical and textural aspects of the turbidite sandstones under plane-polarized light. In parts $\mathbf{f}$ and $\mathbf{g}$, the calcite cement is colored in red. The eodiagenetic and some early mesodiagenetic stages can be observed throughout. a Discontinuous growth of quartz beyond the initial detrital grain boundaries; $\mathbf{b}$ Growths of albite replacing fractured plagioclase grains with no twinning (thereby, healing the intragranular fractures) and also replacing lamellar-twined grains of plagioclase; $\mathbf{c}$ Intragranular porosity by dissolution and replacement of feldspars into kaolinite. Albitization is observed more intense at the highly angular edges, much less along the flat edges, and within fractures of the plagioclase grains without twining (grain at the top-right corner); $\mathbf{d}$ Plagioclase grains heterogeneously albitized; e Kaolinite replacing feldspar grains and filling the intergranular pore spaces; $\mathbf{f}$ Sandstone cemented with poikilotopic pre-compaction calcite; $\mathbf{g}$ Poikilotopic pre-compaction calcite cementing grains that were initially replaced by pyrite and microcrystalline dolomite; and $\mathbf{h}$ Microcrystalline pre-compaction dolomite and pyrite replacing grains and recrystallization of biotite lamellae 


\section{Geological background}

The ESB, developed initially as a part of series of rift basins during Late Jurassic-Early Cretaceous in the southeast of Brazil, has several stages of syn-rift, post-rift and drift sedimentation during and after the Gondwana Breakup (Fig. 2).During the Aptian rift-drift transition, the basin experienced widespread accumulation of evaporite (i.e., Itaúnas Member of the Mariricu Formation; IT in Fig. 2). Since then, the basin remained in a long deep-water sediment-gravity-flow depositional regime of a passive-margin tectonic setting. The Urucutuca Formation defines the entire internally-undifferentiated passive-margin succession of the deep-marine deposits that range in age from the Late Cretaceous to Quaternary. These sediments were deposited beyond the shelf edge. The succession contains mostly turbidity channel-levee complexes and splays encased in the muddy deep-marine deposits. The progressive halokinesis (i.e., ductile and subsurface salt movement) was the result of differential burial and loading above the evaporite horizon (i.e., Itaúnas Member; Fig. 2). The evolution of the basin, sedimentation events, and stratigraphic history of the basin is further discussed elsewhere in detail (e.g., Chang et al. 1992; Cainelli and Mohriak 1999; França et al. 2007; Mohriak, Nemčok and Enciso 2008; Alves 2012).

The Cangoá Field, discovered in May 1988 and located in the ESB, is predominantly characterized by gas accumulation associated with a small volume of oil (Bezerra 2011; Teixeira and Vincentelli 2017). The hydrocarbon is accumulated in the arkosic turbidite sandstone beds rich in feldspar grains. The strata belong to the Eocene interval of Urucutuca Formation (Fig. 2). The turbidite beds were later deformed against the salt dome which conditioned the hydrocarbon entrapment and diagenetic changes (N.B. For regional petroleum geology and stratigraphic context, see Beglinger, Doust and Cloetingh., 2012; and to visualize the seismic-stratigraphic stacking pattern, refer to URL 1 in the references).

\section{Methods and data}

\subsection{Diagenesis of the Eocene turbidite reservoirs of the Cangoá field}

The detailed petrographic analysis and petrological interpretation of the reservoir (both are beyond the scope of this present article) suggest a diagenetic history divided into 4 stages: (1) The marine eodiagenesis, (2) The meteoric eodiagenesis, (3) The compactional mesodiagenesis, and (4) The thermobaric mesodiagenesis. (Fig. 3a-h; sensu Galloway 1984; Worden and Burley 2003; de Oliveira et al. 2018). Since there is no considerable exhumation involved for the samples collected from the drilled wells, any telodiagenetic episode is not observed.

\subsection{Diagenetic processes}

The marine eodiagenetic episode consists of the earliest diagenetic processes as recognized in the turbidites before the maximum compaction sets in. In all the implicit photomicrographs in Fig. 3, the eodiagenetic mineralogical and textural attributes can be discerned. The processes include the disseminated and scarce precipitation of pyrite, dolomite, and siderite, thereby, partially replacing the biotite grains, mudstone intraclasts, and also filling the intragranular porespaceswithin foraminifera bioclasts (de Oliveira et al. 2018). The paragenetic relationships suggest their precipitation through the reduction processes of iron and sulfate by microbial action within marine connate fluids (Berner 1981, 1984; Morad 1998). Also during the meteoric eodiagenesis, the dissolution and initial kaolinization of feldspar and mica grains and mudstone intraclasts concomitant with enlargement of the mica grains are common in the turbidite beds. These processes were enabled by the influx of meteoric water through the reservoir strata when they were still at shallow depths-a common phenomenon that have ubiquitously occurred in all the deep-water sediment-gravity flow deposits of the Brazilian passivemargin basins (Moraes 1989; Carvalho, De Ros and Gomes 1995; Mansurbeget al. 2012). The influx of meteoric water was suited and favored by the hydraulic gradient that was provided by the extensive uplift of the Serra do Mar during the Eocene (Gallagher, Hawkesworth and Mantovani. 1995; Saenz et al. 2003).

During the mesodiagenesis which is contemporaneous with the maximum burial compaction, the mudstone intraclasts and the pseudomatrix derived from the partial to full compressive disintegration of the intraclasts were replaced by the microcrystalline silica (de Oliveira et al. 2018). In a deep-marine depositional setting, this process is usually related to the dissolution of radiolaria or other siliceous organisms in the surrounding shales (van Bennekomet al. 1989; Moraes, 1989; Carvalho, De Ros and Gomes 1995). With increasing burial state, coeval pressure dissolution and recrystallization of quartz grains can be observed, particularly in contact with the micaceous lamellae and carbonaceous fragments, which are potential sources of silica for the quartz overgrowths (de Oliveira et al. 2018).

During the thermobaric mesodiagenesis with the continued subsequent burial, the flow of heat and influx of fluids related to the adjacent salt dome began to influence the reservoirs. The convection of fluids derived from the subjacent shales and carbonates through fracture systems along/around the wall of salt dome promoted the development of hot brine fluids with high $\mathrm{Na}^{+}, \mathrm{Ca}^{2+}, \mathrm{Mg}^{2+}, \mathrm{Cl}^{-}$, and $\mathrm{SO}_{4}{ }^{2-}$ activities. The most evident consequence of the action of these fluids in the vicinity of salt dome is extensive albitization of the detrital 
feldspar grains in the sandstone beds, particularly of the twinned plagioclase and the orthoclase grains (Fig. 3a-h and section 3.2; de Oliveira et al. 2018).

For comparing with other similar eo- and mesodiagenetic situations, the readers can refer to analog examples around the world (e.g., Hanor 1994, 1999; Land, Milliken and McBride 1987; McManus and Hanor 1988, 1993; Posey and Kyle 1988; Ranganathan and Hanor 1988; Evans and Nunn 1989; Evans, Nunn and Hanor 1991; Gaupp et al. 1993; Esch and Hanor 1995; Sarkar, Nunn and Hanor 1995; Giles et al., 2000; Haszeldine et al. 2000; Sharp Jr. et al. 2001; Enos and Kyle 2002; Archer et al. 2004; Milliken 2005; Hanor and McIntosh 2007).

\subsection{Turbidite diagenesis at the inter- and intra-particular scale}

Quartz is observed to be the most abundant detrital constituent with great dominance of monocrystalline grains upon polycrystalline. The presence of diagenetic quartz is common in the turbidites studied, occurring as discontinuous growth covering the grain and as healed fractures of quartzo-feldspathic grains (Fig. 3a-b, g-h).

Albite is the most common diagenetic constituent product in the studied sandstones (up to 18\%; average of $8 \%$ of the total rock volume), predominantly replacing detrital feldspars. Albitization in and along the lamellar twins of plagioclase and orthoclase grains is observed to be much more intense than the same in plagioclase grains without twinning and in microcline. In the latter 2 varieties of feldspar, albitization is found typically limited to the grain boundaries and grain fractures (Fig. 3b, d). Growths of authigenic albite can be observed discontinuously around the plagioclase grains-much intense at the sharper edges, less along the flatter grain boundaries, and also along the fractures (Fig. 3c).

Kaolinite, which is a major concern for the production geologists, is the main clay mineral of the Eocene turbidites in the Cangoá Field. Kaolinite occurs predominantly as the replacement of primary mineral constituents and intergranular pore-filling materials. Authigenic kaolinite is predominantly related to the dissolution of feldspars grains (Fig. 3c). The kaolinite grains occur as aggregates that intensely replaced the feldspar grains (Fig. 3e). The aggregates, when observed in further higher resolution (e.g., in scanning electron microscopy), have vermicular appearance. Intense kaolinization has created intragranular and intrafracture microporosity. The aggregates which filled the intergranular pores or replaced the mudstone intraclasts and mud pseudomatrix are thinner, and have little microporosity. The kaolinization of the micas is also quite common causing the aggregates dilate as fan or accordion and intermittently expand to adjacent pores. Kaolinization and dissolution of feldspar grains are very invasive and intense in the cuttings and cored samples where the grains are fractured.
The distribution of calcite and paragenetic relationship with other phase(s) in the samples show that the calcite precipitation occurred in two stages:

1) The early pre-compaction to syn-compaction authigenesis and

2) The later post-compaction precipitation.

Early-precipitated calcite grains demonstrate their concretion-like distribution. These crystals/grains are macrocrystalline to poikilotopic (Fig. 3f-g) and pore-filling intergranular in texture. The authigenic precipitation of early calcite seems to have volumetrically dilated the mica grains, engulfed, and partially replaced the kaolinite grains and aggregates. The cementation of large intergranular volume implying a loose packing of sand grains indicates that the early calcite precipitation occurred at a very shallow-depth interval before any significant burial could take place. The late post-compactional calcite precipitation seems to have occurred also with the macrocrystalline-poikilotopic habit and, however, with more ferrous composition. The late ferroan calcite cement seems to have filled the intermittent narrow intergranular pores in the normal or tightly packed sandstones, often thereby replacing grains and wrapping the overgrowths of quartz and albite, or late dolomite grains/crystals.

Similar to the calcite cement, also the petrographic characteristics of dolomite cementation indicate that the dolomite precipitation occurred in 2 phases in the studied turbidites:

1) The early pre-compaction and

2) The late post-compaction.

The early dolomite crystals occur dominantly as microcrystalline grains typically associate with biotite lamellae. The biotite lamellae appear to have been replaced, dilated, and intermittently nesting and impregnating the derivative framboidal pyrite or microcrystalline dolomite crystals (Fig. 3g-h). The late authigenic dolomite, very similar to the late calcite, occurs as the macrocrystalline blocky cement which sporadically appears in both ferrous and non-ferrous compositions and dominantly fills the intergranular pores reduced by the ensuing compaction. Sparcely, the late dolomite cement also appears to have replaced the calcite and plagioclase grains and wrapped the overgrowths of albite and quartz grains and the kaolinite aggregates.

\section{Computerized geochemical models}

\subsection{Schematic diagenetic fluid-flow model}

A conceptual schematic fluid-flow model, which is constructed based on integrating the petrographic observations and the seismic stratigraphic interpretation, demonstrates 
the flow paths of fluids have influenced diagenesis of the Eocene turbidite reservoirs (Fig. 4). The fluid-flow model provides the spatial understanding how the diagenetic alterations took place under the influx of water carrying solutes from outside the turbidite formation(s), marked in light blue in Fig. 4.

\subsection{Data: primary mineralogical and fluid compositions used for modeling}

The reservoir geometry and the thermal history were estimated from the burial history and current field conditions. In order to formulate and run the geochemical simulation in the computer programs, the petrographic observations by de Oliveira et al. (2018), as described above, have been simplified considering only the most important mineral phases that are able to reconstruct each stage of thermobaric diagenetic history. The mineralogical compositions of the reservoir turbidites and the non-reservoir mud rocks ("shales") to be modeled are shown in Table 1. In order to reconstruct the thermobaric mesodiagenetic condition, the interaction of a highly saline fluid with the mineral grains of reservoir units is considered as shown in Fig. 4. The high salinity of the advecting fluid was attained while its interaction with the salt dome. The conceptual model considers the percolation of relatively low-salinity fluid from the shale (and other lithologies) underlying and/or overlying the turbidite strata. This advective percolation was run by the thermal contrast caused by the salt dome. The original modal percentages of the major rock-forming minerals and types of porosity were approximately estimated based on the pockets of unaltered petrofacies from borehole data (Table 2). At the granular scale, only the intergranular diagenetic reactions are modeled here because the intragranular systems would have been in isolation, therefore, rendering highly limited impact on the reservoir quality.

The compositions of waters used for the model were assumed to be:

1) Average brackish formation water values as the analog from Gulf of Mexico (Tempel and Harrison 2000; Table 3) for the fluids that promoted the meteoric diagenesis processes (i.e., dissolution and

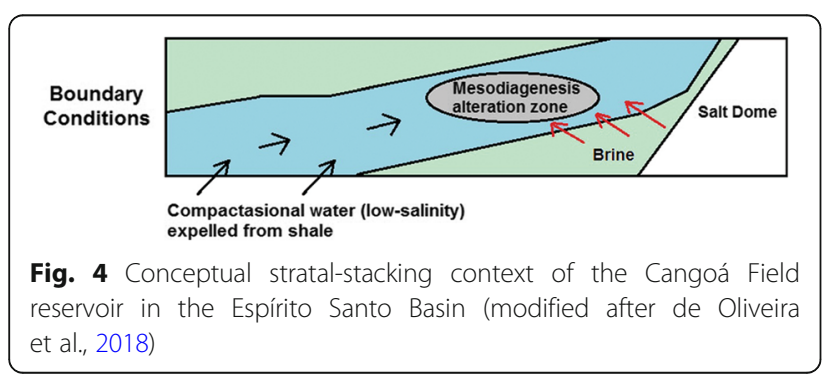

Table 1 Modal (i.e., volume percentage) mineralogical composition of sandstone and shale as constrained in the computer-based geochemical models

\begin{tabular}{lll}
\hline Mineral & Sandstone (\%) & Shale (\%) \\
\hline Quartz & 46.35 & 21.15 \\
K-feldspar & 8.40 & 3.2 \\
Plagioclase & 12.00 & 4.0 \\
Albie & 0.3 & 4.1 \\
Calcite & 0.3 & 2.7 \\
Dolomite & 1.10 & 1.9 \\
Kaolinite & 4.35 & 3.15 \\
Illite & 5.5 & 49.5 \\
Chlorite & 0.5 & 4.5 \\
\hline
\end{tabular}

kaolinization of the feldspar and mica grains and of the mudstone intraclasts; enlargement of mica grains in expense of kaolinite);

2) Average saline formation water from the Gulf of Mexico as the analog (Tempel and Harrison 2000; Table 3) for the fluids expelled during the compaction of subjacent shales;

3) Current formation water (brine) from a borehole for the thermobaric fluid composition related to the salt dome (Table 4).

Table 2 The average volume percentages of the major mineral constituents of petrofacies associations recognized in turbidite sandstones of the Espírito Santo Basin as encountered in the Well A1

\begin{tabular}{lll}
\hline Constituents & Well $-\mathrm{A} 1$ \\
\cline { 2 - 3 } & Porous (\%) & Micaceous (\%) \\
\hline Detrital Quartz & 48.42 & 34.78 \\
Detrital K-feldspar & 8.50 & 9.11 \\
Detrital Plagioclase & 12.88 & 18.89 \\
Micas & 0.71 & 1.78 \\
Carbonate grains & 1.46 & 0.88 \\
Intergranular Albite & 0.51 & 0.89 \\
Intragranular Albite & 3.04 & 4.88 \\
Intergranular Calcite & 0.71 & 0.44 \\
Intragranular Calcite & 1.83 & 0.78 \\
Intergranular Dolomite & 0.88 & 0.22 \\
Intragranular Dolomite & 1.33 & 0.66 \\
Intergranular Kaolinite & 0.79 & 0.33 \\
Intragranular Kaolinite & 2.74 & 3.99 \\
Intergranular Quartz & 3.00 & 2.33 \\
Intragranular Porosity & 5.25 & 6.44 \\
Intergranular Porosity & 2.20 & 2.65 \\
Sum & 94.27 & 89.06 \\
\hline
\end{tabular}


Table 3 Composition of the meteoric fluids and the fluids derived from the compaction of shale used in the simulation. Fluid composition is assumed as documented in the Eocene of Gulf of Mexico as an analog (Tempel and Harrison, 2000)

\begin{tabular}{lll}
\hline Solutes & Meteoric Water $(\mathrm{mg} / \mathrm{L})$ & Compaction Water $(\mathrm{mg} / \mathrm{L})$ \\
\hline $\mathrm{Na}^{+}$ & 6.30 & 29.80 \\
$\mathrm{~K}^{+}$ & 2.30 & 230.00 \\
$\mathrm{Ca}^{2+}$ & 15.00 & 1490.00 \\
$\mathrm{Mg}^{2+}$ & 4.10 & 151.00 \\
$\mathrm{Cl}^{-}$ & 15.00 & $476,300.00$ \\
$\mathrm{SO}_{4}{ }^{2-}$ & 11.20 & 18.00 \\
$\mathrm{SiO}_{2(\mathrm{aq})}$ & 13.10 & 84.00 \\
$\mathrm{Fe}^{2+}$ & 1.00 & 100.00 \\
$\mathrm{Al}^{3+}$ & 0.01 & 0.01 \\
$\mathrm{HCO}_{3}{ }^{-}$ & equil CO \\
$\mathrm{H}^{+}$ & $3.16 \mathrm{E}-7$ & equil CO \\
$\mathrm{pH}^{2}$ & 6.50 & $3.16 \mathrm{E}-6$ \\
\hline
\end{tabular}

\subsection{Computer simulation packages used}

Although there are many software packages available for simulating geochemical reactions, for this current study we used the Geochemist's Workbench $\left(\mathrm{GWB}^{\mathrm{rx}}\right)$, PHREEQC $^{\mathrm{TM}}$, and TOUGHREACT ${ }^{\mathrm{T} M}$.

The software package $\mathrm{GWB}^{\mathrm{Tm}}$ was developed by the Department of Geology of University of Illinois at Urbana-Champaign in 1978. It performs simple simulations for calculating the saturation index (SI; i.e., $\log \mathrm{Q} /$ $\mathrm{K}$, where $\mathrm{K}$ is the chemical kinetic parameter or equilibrium chemical activity and $\mathrm{Q}$ is the chemical activity of the reaction products; the ratio $\mathrm{Q} / \mathrm{K}$ represents the departure of the system from equilibrium; see Stumm and

Table 4 Composition of the thermobaric fluid related to the salt dome used in the model. The formation-water composition of the modelled stratigraphic horizon of the Well $A 1$ is considered as an analog in the model (courtesy PetróleoBrasileiro S.A. - Petrobras)

\begin{tabular}{ll}
\hline Solutes & Sample 1 (mg/L) \\
\hline $\mathrm{HCO}_{3}{ }^{-}$ & 794.00 \\
$\mathrm{Br}^{-}$ & 25.00 \\
$\mathrm{Ca}^{2+}$ & 3377.00 \\
$\mathrm{Cl}^{-}$ & $62,517.00$ \\
$\mathrm{Sr}^{2+}$ & 408.00 \\
$\mathrm{Fe}^{2+}$ & 50.00 \\
$\mathrm{I}^{-}$ & - \\
$\mathrm{Mg}^{2+}$ & 345.00 \\
$\mathrm{~K}^{+}$ & 7640.00 \\
$\mathrm{Salinity}^{2+}$ & $103,060.00$ \\
$\mathrm{Na}^{+}$ & $32,349.00$ \\
$\mathrm{SO}_{4}{ }^{2-}$ & 1694.00 \\
\hline
\end{tabular}

Morgan 2012) within a short time interval using Debye and HückelHarvie-Møller-Weare models (Bethke 2002) and distribution of aqueous species.

The PHREEQC ${ }^{\mathrm{TM}}$ is a software program freely available in public domain. It is written in the $\mathrm{C}$ and $\mathrm{C}++$ programming codes and is designed to perform a wide range of geochemical calculations. The PHREEQC ${ }^{\mathrm{rm}}$ calculates the SI and speciation in batch mode and one-dimensional (1-D) transport. The PHREEQC ${ }^{\mathrm{rm}}$ uses the Pitzer model (Helgeson, Garrels and MacKenzie 1969) where the salinity of water is high and outside the application ranges of Debye-Hückel theorem (Helgeson, Kirkham and Flowers 1981). The software uses the numerical integration method, allowing the solution of differential equations that can be generalized for the reconstruction of three-dimensional trajectories (Parkhurst 1995; Parkhurst and Appelo 1999, 2013).

The TOUGHREACT ${ }^{\mathrm{TM}}$ software package was developed to simulate fluid flow in a non-isothermal, multicomponent, and geochemical transport. The aim of the package is to investigate problems involving simple and complex geological environments (Xu and Pruess 1998). The TOUGHREACT ${ }^{\mathrm{TM}}$ can also use batch modes, thereby, simulating the reactions in a closed system. A number of thermo-physical and chemical processes occurring in the subsurface are assumed to be under the hydrological geochemical conditions, e.g., pressure, temperature, water saturation, and ionic strength. The numerical solution to the water-rock interaction is based on the finite difference (Narasimhan and Witherspoon 1976). These equations are solved by the Newton-Raphson interaction (Pruess 1991). The activity coefficient is calculated using the Debye-Hückel equation.

\section{Results}

\subsection{Simulations in batch mode}

Batch mode simulations were performed at $120{ }^{\circ} \mathrm{C}$, corresponding to the mesodiagenetic conditions in which the sandstones were percolated by the compactational fluid influx (Fig. 5). The software packages used for modeling in the batch condition were the $\mathrm{GWB}^{\mathrm{Tm}}$, PHREEQC $^{\mathrm{Tm}}$, and TOUGHREACT ${ }^{\mathrm{Tm}}$.

Typically, for sediments buried at very shallow depths, the temperature rises over the time of burial. The water-rock interactions increase with increasing depth of burial and tend to achieve the chemical equilibria. The batch mode aims to achieve this steady state in accordance with the observed petrographic characteristics. Because of the changes in temperature and fluid flow, the pore water cannot attain a chemical equilibrium with its surrounding mineral phases. The diagenetic reactions are, therefore, the result of this continued tendency towards a state of progressive equilibrium that never attains a finite state. For this reason, a condition 

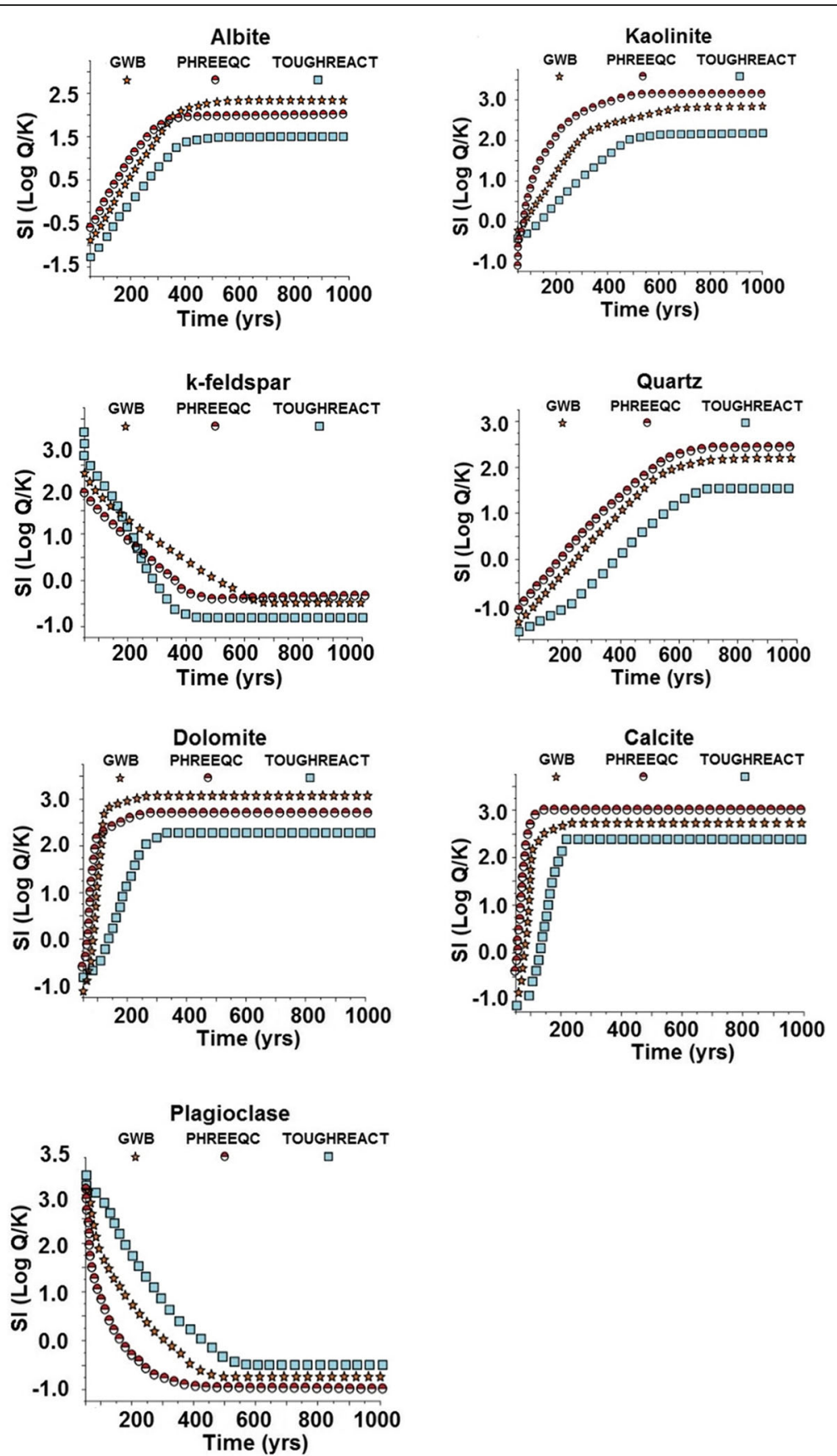

Fig. 5 Mineral saturation for batch mode simulation of shale at $120{ }^{\circ} \mathrm{C}$ for 1000 years. The water in start simulation is significantly in nonequilibrium with the rock. Over the time, the composition of water evolves to approach the equilibrium plateau and the relative saturations of mineral converge to a "steady state"

approximate to a "steady state" is more appropriate and prudent to describe the geochemical state of rocks and diagenetic fluids.

Figure 5 furnishes the progress of diagenetic reactions for the simulations in batch mode. Minerals are initially far from equilibrium. Over the time, the minerals attain the "steady-state" condition. The aforementioned three geochemical modeling packages demonstrate this similar behavior in the precipitation and dissolution of the mineral assembly. We also observed the phenomena of intense kaolinization and K-feldspar dissolution.

We observed a process of albitization of plagioclase grains. The model also shows calcite precipitation and dolomite filling the intergranular pores. Quartz 

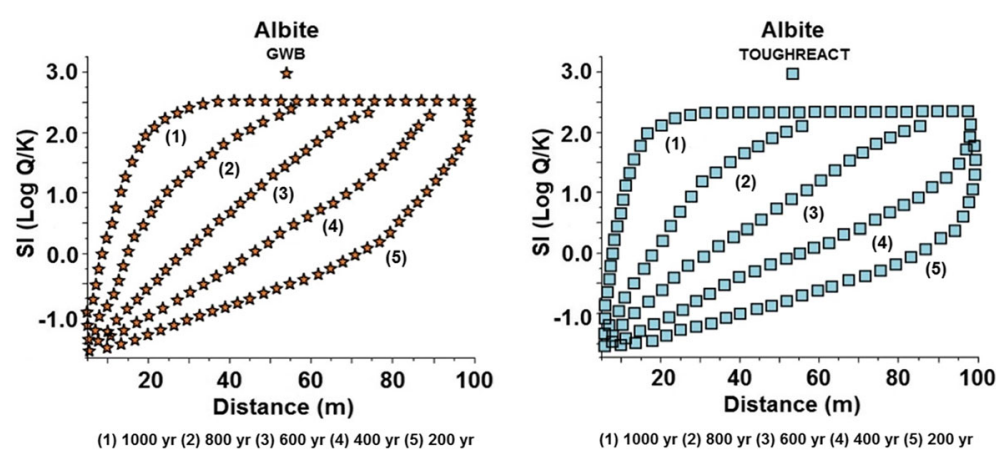

(1) $1000 \mathrm{yr}$ (2) $800 \mathrm{yr}$ (3) $600 \mathrm{yr}$ (4) $400 \mathrm{yr}$ (5) $200 \mathrm{yr}$

Fig. 6 Saturation index (SI) of albite in 1-D simulation (shale-sandstone system) using GWB and TOUGHREACT. Both the plots display the relationship between the $\mathrm{SI}$ and the distance from the reaction front at 5 different times. The petrographic evidence of the albite-precipitation reaction texture can be observed in Fig. 3b-c

overgrowths are suggested to have been co-precipitated along with albite. There is a minute discrepancy in the models generated by the TOUGHREACT ${ }^{\mathrm{rm}}$ due to the numerical method used for reactions occurring above $100{ }^{\circ} \mathrm{C}$. However, for the GWB ${ }^{\mathrm{rm}}$ and PHREEQC ${ }^{\mathrm{mix}}$, using a similar numerical method in this temperature range, the plotted profiles appear practically the same.

\subsection{1-D simulations}

The 1-D simulations (Figs. 6, 7, 8, 9, 10, 11 and 12) were performed using the previous results of the batch mode simulations. The applied simulation domain has a width of $100 \mathrm{~m}$ at $140{ }^{\circ} \mathrm{C}$ (i.e., the temperature referring to the thermobaric mesodiagenesis). The numerical cell resolution has 1 grid per meter. The first part of simulation domain consists of $10 \mathrm{~m}$ of shale and $90 \mathrm{~m}$ of sandstone. These simulations reveal that, for a short time, the minerals do not attain the steady state. With the development of water pushed out from the shale beds towards the sandstones, the minerals reacted with the surrounding environment, achieving stability as the simulation time went by.

Approximately around 600 years after the onset of water-rock interactions, the modeled stability of minerals is shown to have attained. The $\mathrm{GWB}^{\mathrm{m}}$ and TOUGHREACT $^{\mathrm{Tx}}$ exhibit similar behaviors for the evolving system of interaction. In the 1-D simulations, the results show similar behaviors to those observed in the petrographic analysis in Fig. 3.

\section{Discussion}

The simulations modeled the effects of circulation of fluids that evolved due to the interaction of expelled formation water from intercalated mud-rock ("shale") bodies with the salt dome near the turbidite reservoir formations during the thermobaric mesodiagenetic regime.

The meteoric eodiagenetic stage is marked by an intense kaolinization. The authigenic precipitation of carbonate, silicification of lithic grains, and a part of quartz overgrowth are the typical diagenetic products of the compactional mesodiagenesis while the turbidite formations were progressively affected by the connate fluid flow supplied by the surrounding shales.

In the last stage of mesodiagenesis, i.e., the thermobaric mesodiagenetic episode, the reactions were influenced by the effects of brine percolation from the salt
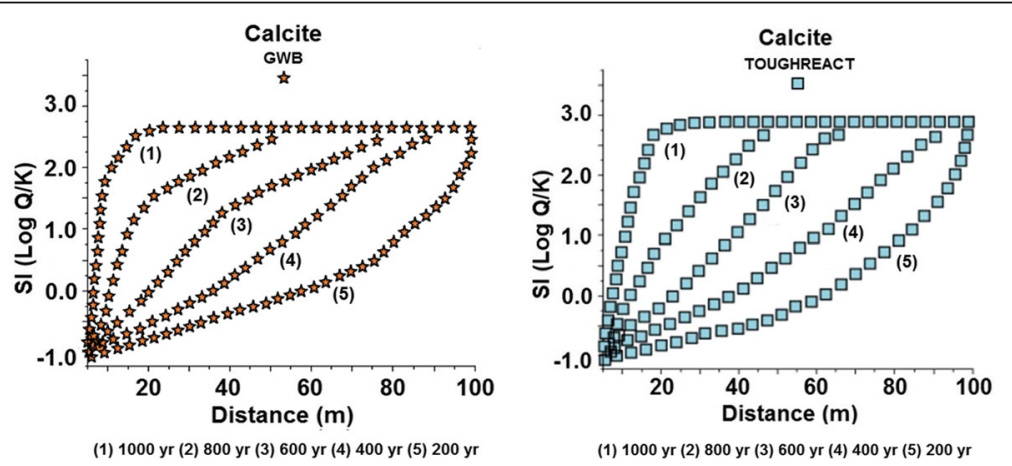

Fig. 7 Saturation index (SI) of calcite in 1-D simulation (shale-sandstone system) using GWB and TOUGHREACT. The plots show the relationship between the SI and the distance from the reaction front at 5 different times. See Fig. 3F-G for the reaction texture of calcite precipitation 

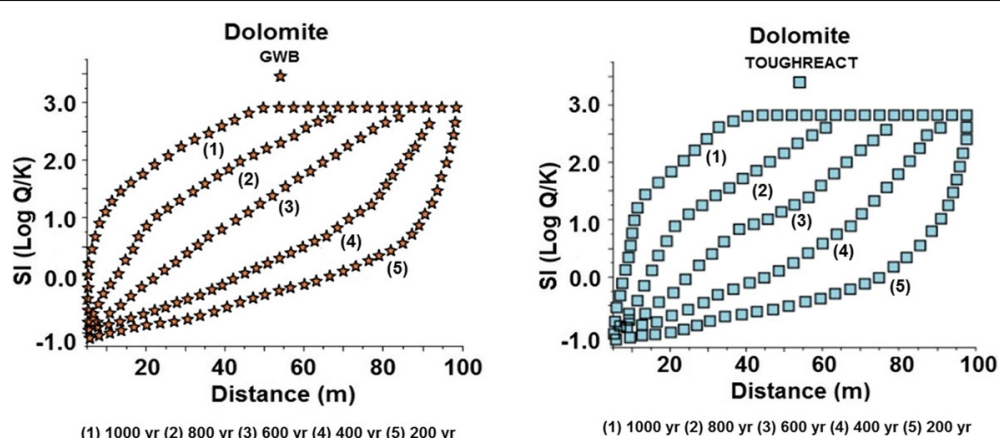

Fig. 8 Saturation index (SI) of dolomite in 1-D simulation (shale-sandstone system) using GWB and TOUGHREACT. The plots here demonstrate the relationship between the $\mathrm{SI}$ and the distance from the salt-dome reaction front at 5 different times. See Fig. $3 g-h$ for petrographic manifestation of the dolomite crystallization

diapirs that penetrated and disrupted the deep-water sedimentary succession. Typical diagenetic products of this interaction were the intense albitization of plagioclase grains and the remaining quartz overgrowths around the detrital framework grains.

While the meteoric diagenesis and the compactionalmesodiagenesis decrease the turbidite sandstone porosity, the thermobaric mesodiagenesis introduced reservoir heterogeneity due to substantial porosity variations within the reservoir bodies. This signifies why the reconstructed geochemical model is focused on the mesodiagenetic later reactions. Initially, the simulations were performed in batch mode (Fig. 5) due to geochemical instability between the water and the formation minerals. Once a steady state is attained, this chemically stable water-mineral system can be modeled in 1-D. From the shale horizons, the brine percolates through the sandstone beds, thus, forming a reactional front inside the reservoir.

Depending on the reactions as observed in the geochemical modeling, it shows the petrophysical quality of reservoir horizons being affected with a mineralogical paragenetic pattern. For the prediction and analysis of reservoir quality, a large number of simulations were performed with variable water composition, temperature, and fluid flow rate.
Regarding the geochemical modeling software packages used in batch mode in these simulations, we can identify the similarities among the reaction profiles generated by precipitation and dissolution. The minuscule differences observed among the simulations arising from varying software packages depend on the corresponding numerical methods used by each individual simulator. Nevertheless, they do not signify much discernible discrepancies among the outputs, or in other words, among the petrophysical properties of the final products in spite of the fact that we have to take into account that both the kinetic and thermodynamic parameters are affected by high temperature reaction conditions.

Each simulator solves the equations of diagenetic reactions based on these parameters. The $\mathrm{GWB}^{\mathrm{rm}}$ and PHREEQC $^{\mathrm{m}}$ reconstruct the diagenetic reactions in batch mode more precisely by using the numerical approximations at a temperature of $120{ }^{\circ} \mathrm{C}$.

However, the TOUGHREACT ${ }^{\mathrm{Tm}}$ reproduces the diagenetic reactions somewhat differently by using the temperature parameter of $140{ }^{\circ} \mathrm{C}$, which results in a slight instability in the numerical method because of the kinetic and thermodynamic parameters applied. The 1-D simulations are shown in Figs. 6, 7, 8, 9, 10, 11 and 12 , in which the plots display the mineral-phase
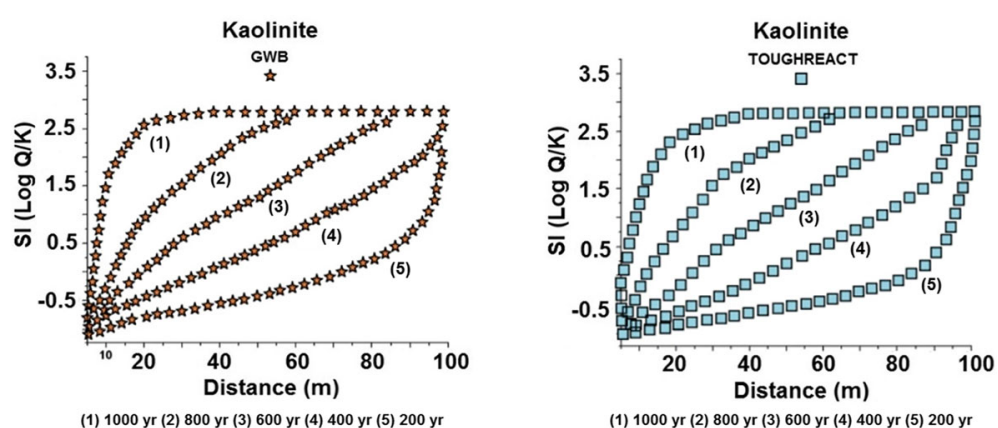

Fig. 9 Saturation index (SI) of kaolinite in 1-D simulation (shale-sandstone system) using GWB and TOUGHREACT. The plots here display the relationship between the $\mathrm{SI}$ and the distance from the salt-dome reaction front at 5 different times 

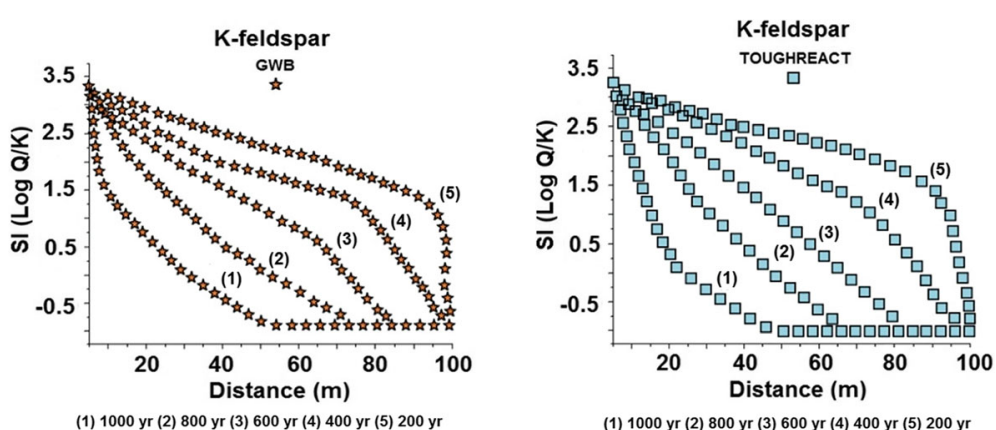

Fig. 10 Saturation index (SI) of K-feldspar in 1-D simulation (shale-sandstone system) using GWB and TOUGHREACT. The plots here show the relationship between the $\mathrm{SI}$ and the distance from the salt-dome reaction front at 5 different times. See Fig. 3e for petrographic manifestation of the kaolinite replacing feldspar particles

saturation at five different times $(200,400,600,800$, and 1000 years from the onset of corresponding diagenetic reactions) by using the $\mathrm{GWB}^{\mathrm{m}}$ and TOUGHREACT $^{\text {ma }}$. In general, with the time step, the minerals attain a steady state. Due to the high temperatures $\left(140{ }^{\circ} \mathrm{C}\right)$ of the thermobaric mesodiagenesis, the saturation indices of the mineral assembly became slightly different.

Let us compare the petrographic observations (as in the implicit photomicrographs or TS, in Fig. 3) and the 1-D reactions (or GM; Figs. 6, 7, 8, 9, 10, 11 and 12). The precipitation of kaolinite filling (GM: Fig. 9) the secondary porosity formed by the dissolution of feldspar grains (e.g., TS: Fig. 3e; GM: Fig. 10) has been recognized in several samples which were obtained from the same stratigraphic horizon which were partially cemented by carbonates (e.g., TS: Fig. 3g-h; GM: Figs. 7 and 8).

The models corroborate the dissolution of K-feldspar (e.g., TS: Fig. 3c; GM: Fig. 10) and plagioclase (e.g., TS: Fig. 3d; GM: Fig. 11) with albite precipitation (e.g., TS: Fig. 3b-c; GM: Fig. 6). The precipitation of calcite (e.g., TS: Fig. 3f-g; GM: Fig. 7) in sandstones occurs while the calcite solubility decreases with increasing temperature.
The precipitation of dolomite (e.g., TS: Fig. 3g-h; GM: Fig. 8) occurs after the calcite precipitation.

The discontinuous quartz overgrowth (e.g., TS: Fig. 3a; GM: Fig. 12) represents the first mesodiagenetic event of importance in the studied sandstone horizons. The source of silica cementation can be related to: (1) The pressure dissolution of quartz grains, (2) The smectite to illite clay transformations during burial, thereby, releasing silica, (3) The kaolinization or dissolution of feldspar grains in the immature arkosic turbidite sandstones, and 4) The dissolution of quartz grains in the shale layers.

\section{Conclusions}

1) The Eocene turbidite sandstone reservoirs of the Espírito Santo Basin, Brazil, had their diagenetic history developed under the eodiagenetic and mesodiagenetic regimes. The relationships among the events of cementation, dissolution, and replacement in the sandstone allow us to establish the temporal sequence of diagenetic events.

2) As a unique study with a computer-simulation approach of the diagenetic alteration of turbidite
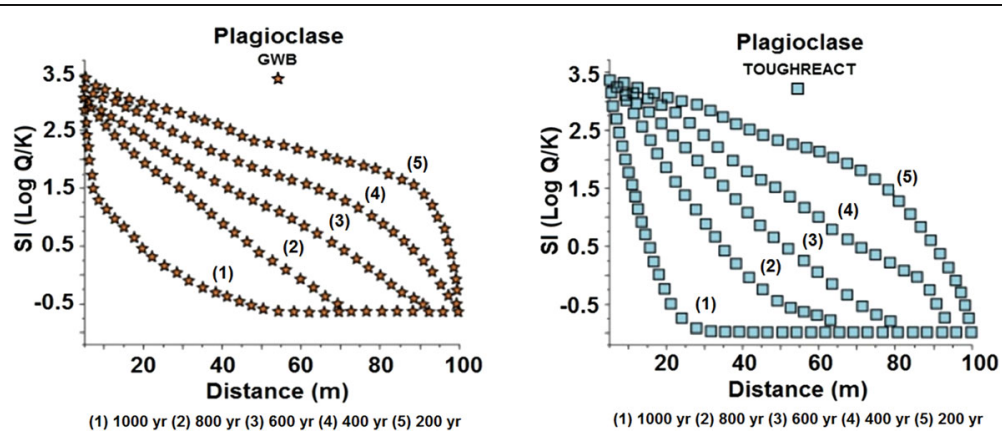

Fig. 11 Saturation index (SI) of plagioclase in 1-D simulation (shale-sandstone system) using GWB and TOUGHREACT. The plots here show the relationship between the SI and the distance from the salt-dome reaction front at 5 different times. See Fig. $3 \mathrm{~d}$ for petrographic manifestation of the heterogeneous albitization of plagioclase grains 

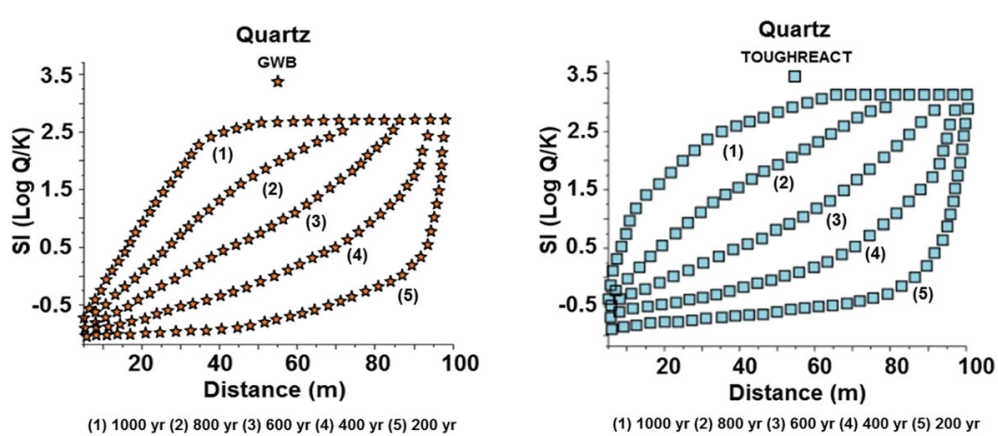

Fig. 12 Saturation index (SI) of quartz in 1-D simulation (shale-sandstone system) using GWB and TOUGHREACT. The plots here show the relationship between the $\mathrm{SI}$ and the distance from the salt-dome reaction front at 5 different times. See Fig. 3a which display discontinuous overgrowth of the quartz grains

sandstones exposed to a saline water flow, the geochemical modeling software packages (i.e., GWB $^{\mathrm{Tm}}$, PHREEQC ${ }^{\mathrm{mm}}$, and TOUGHREACT ${ }^{\mathrm{mm}}$ ) has been successful in simulating the diagenetic events and their temporal sequences as observed and corroborated in the thin sections. The simulations in the batch mode enabled the formation waters to achieve the steady state which lets the modeler to use the equilibrated compositions for the 1-D simulations. The time required for the shale and sandstone horizons to reach the steady state depends on the grain size of each lithofacies.

3) The 1-D simulation approach establishes itself as a method of estimating the intensity of albitization in response to the saline-fluid inflow into reservoir bodies with the concomitant precipitation of kaolinite and dissolution of plagioclase.

4) The marine eodiagenetic regime has been characterized by dissolution of the unstable minerals and the authigenic precipitation of microcrystalline calcite, pyrite, and K-feldspar. The meteoric eodiagenesis was promoted by the circulation of meteoric water which caused dissolution and kaolinization of the feldspar and mica grains.

5) Under the mesodiagenetic condition, the sandstone strata were percolated by compactational and thermobaric fluids, thereby, resulting in different diagenetic processes, e.g., quartz overgrowths, plagioclase dissolution, cementation by calcite and dolomite, further dissolution of feldspars, the precipitation of kaolinite, and albitization of feldspars.

6) The sandstone porosity is represented by the intergranular, intragranular, and fracture types of pores. The porosity decreases towards a reaction front/zone where water from the shale horizons comes in contact with the sandstones.

\section{Acknowledgements}

The authors express their special thanks to Carla Maria Dal Sasso Freitas, Renata de Matos Galante, Luiz Fernando De Ros, and to Leonardo Hax Damiani for their valuable help. This research was supported through funding from the Petrobras. Elaborate, critical, and diligent review of the manuscript was performed by Yuan Wang and two anonymous reviewers to whom the authors convey their utmost gratitude. We are grateful to the facilities available at the Informatics Institute, the Isotopic Geology Laboratory, the Graduate Program in Geosciences at the Geosciences Institute of the Federal University of Rio Grande do Sul, Brazil, and the IIT Bombay, India.

\section{Authors' contributions}

MAK carried out the computerized geochemical modelling. SD evaluated the sedimentological feasibility and verified the depositional credentials of the computer model and sedimentological data. SD also performed the technical writing part of the manuscript. RVC supervised the project, conceived the project, and participated.

\section{Competing interests}

No conflict of interest exists.

\section{Publisher's Note}

Springer Nature remains neutral with regard to jurisdictional claims in published maps and institutional affiliations.

\section{Author details}

${ }^{1}$ Institute of Isotope Geology, Federal University of Rio Grande do Sul, Porto Alegre, Brazil. ${ }^{2}$ Department of Earth Sciences, Indian Institute of Technology (IIT) Bombay, Mumbai, India.

Received: 2 January 2018 Accepted: 18 May 2018

Published online: 20 September 2018

\section{References}

Alves, T.M. 2012. Scale-relationships and geometry of normal faults reactivated during gravitational gliding of Albian rafts (Espírito Santo Basin, SE Brazil). Earth and Planetary Science Letters 331: 80-96.

Archer, S.G., H.L. Wycherley, G.R. Watt, M.L. Baron, J. Parnell, and H. Chen. 2004. Evidence for focused hot fluid flow within the Britannia field, offshore Scotland, UK. Basin Research 16: 377-395.

Beglinger, S.E., H. Doust, and S. Cloetingh. 2012. Relating petroleum system and play development to basin evolution: Brazilian South Atlantic margin. Petroleum Geoscience 18: 315-336.

Berner, R.A. 1981. A new geochemical classification of sedimentary environments. Journal of Sedimentary Research 51: 359-365.

Berner, R.A. 1984. Sedimentary pyrite formation: An update. Geochimica et CosmochimicaActa 48: 605-615.

Bethke, C.M. 2002. The geochemists workbench version 4.0: A User's quide, 224 Urbana, IL: University oflllinois. 
Bezerra, M.F.C. 2011. Developments of Deep Offshore and Deeply Buried Reservoirs. $20^{\text {th }}$ World Petroleum Congress, 20th World Petroleum Congress, 4-8 December, Doha, Qatar. 2011. https://www.onepetro.org/conference-paper/WPC-20-3272.

Cainelli, C., and W.U. Mohriak. 1999. Some remarks on the evolution of sedimentary basins along the eastern Brazilian continental margin. EpisodesNewsmagazine of the International Union of Geological Sciences 22: 206-216.

Carvalho, M.V., L.F., De Ros, and N.S.Gomes. 1995. Carbonate cementation patterns and diagenetic reservoir facies in the Campos Basin cretaceous turbidites, offshore eastern Brazil. Marine and Petroleum Geology 12: 741-758.

Chang, H.K., R.O. Kowsmann, A.M.F. Figueiredo, and A. Bender. 1992. Tectonics and stratigraphy of the East Brazil rift system: An overview. Tectonophysics 213: 97-138.

de Oliveira, D.M. 2018. Diagênese meteórica e relacionada a domos de sal em reservatórios turbiditicos Terciários da bacia do Espírito Santo, Brasil. Masters Thesis: Universidade Federal do Rio Grande do Sul: 1-78 (in Portuguese).

Enos, J.S., and J.R. Kyle. 2002. Diagenesis of the Carrizo Sandstone at Butler Salt Dome, East Texas Basin, USA: Evidence for fluid-sediment interaction near halokinetic structures. Journal of Sedimentary Research 72: 68-81.

Esch, W.L., and J.S. Hanor. 1995. Fault and fracture control of fluid and diagenesis around the Iberia Salt Dome, Iberia Parish, Louisiana. Transactions of the Gulf Coast Association of Geological Societies 45: 181-187.

Evans, D.G., and J.A. Nunn. 1989. Free thermohaline convection in sediments surrounding a salt column. Journal of Geophysical Research: Solid Earth 94 (B9): 12413-12422.

Evans, D.G., J.A. Nunn, and J.S. Hanor. 1991. Mechanisms driving groundwater flow near salt domes. Geophysical Research Letters 18: 927-930.

França, R.L., A.C. Del Rey, C.V. Tagliari, J.R. Brandão, and P.D.R. Fontanelli, 2007. Bacia do Espírito Santo. Boletim de Geociencias da Petrobras 15: 501-509 (in Portuguese).

Gallagher, K., C.J. Hawkesworth, and M.S.M. Mantovani. 1995. Denudation, fission track analysis and the long-term evolution of passive margin topography Application to the southeast Brazilian margin. Journal of South American Earth Sciences 8: 65-77.

Galloway, W.E. 1984. Hydrogeologic regimes of sandstone diagenesis. In Relationship of organic matter and mineral diagenesis, ed. D.A. McDonald and R.C. Surdam, vol. 17, 6-72. New York: Soc. Econ. Paleo. Min., Lecture Notes for Short Course.

Gaupp, R., A. Matter, J. Platt, K. Ramseyer, and J. Walzebuck. 1993. Diagenesis and fluid evolution of deeply buried Permian (Rotliegende) gas reservoirs, northwest Germany. AAPG Bulletin 77: 1111-1128.

Genthon, P., J. Schott, and J.L. Dandurand. 1997. Carbonate diagenesis during thermo-convection: Application to secondary porosity generation in clastic reservoirs. Chemical Geology 142: 41-61.

Giles, M.R., S.L. Indrelid, G.V. Beynon, and J. Amthor. 2000. The origin of largescale quartz cementation: Evidence from large data sets and coupled heatfluid mass transport modeling. Quartz Cementation in Sandstones, IAS Special Publication 29: 21-38.

Hanor, J.S. 1994. Origin of saline fluids in sedimentary basins. In Geological Society of London Special Publication, ed. J. Parnell , vol. 78, 151-174.Geofluids: Origin and migration of fluids in sedimentary basins

Hanor, J.S. 1999. Thermohaline pore water trends of southeastern Louisiana revisited [abs]. AAPG Bulletin 83: 1354

Hanor, J.S., and J.C. McIntosh. 2007. Diverse origins and timing of formation of basinal brines in the Gulf of Mexico sedimentary basin. Geofluids 7: 227-237.

Haszeldine, R.S., C.I. Macaulay, A. Marchand, M. Wilkinson, C.M. Graham, A. Cavanagh, A.E. Fallick, and G.D. Couples. 2000. Sandstone cementation and fluids in hydrocarbon basins. Journal of Geochemical Exploration 69: 195-200.

Helgeson, H.C., R.M. Garrels, and F.T. MacKenzie. 1969. Evaluation of irreversible reactions in geochemical processes involving minerals and aqueous solutions-II. Applications. Geochimica et CosmochimicaActa 33: 455-481.

Helgeson, H.C., D.H. Kirkham, and G.C. Flowers. 1981. Theoretical prediction of the thermodynamic behavior of aqueous electrolytes by high pressures and temperatures; IV, calculation of activity coefficients, osmotic coefficients, and apparent molal and standard and relative partial molal properties to 600 degrees C and 5kb. American Journal of Science 281: 1249-1516.

Klunk, M.A., L.H. Damiani, G. Feller, R.V. Conceição, M. Abel, and L.F. De Ros. 2015. Geochemical modeling of diagenetic reactions in snorre field reservoir sandstones: A comparative study of computer codes. Brazilian Journal of Geology 45: 29-40.

Land, L.S., K.L. Milliken, and E.F. McBride. 1987. Diagenetic evolution of Cenozoic sandstones, Gulf of Mexico sedimentary basin. Sedimentary Geology 50: 195-225.
Mansurbeg, H., L.F. De Ros, S. Morad, J.M. Ketzer, M.A.K. El-Ghali, M.A. Caja, and R. Othman. 2012. Meteoric-water diagenesis in late cretaceous canyon-fill turbidite reservoirs from the Espírito Santo Basin, eastern Brazil. Marine and Petroleum Geology 37: 7-26.

McManus, K.M., and J.S. Hanor. 1988. Calcite and iron sulfide cementation of Miocene sediments flanking the west Hackberry salt dome, Southwest Louisiana, USA. Chemical Geology 74: 99-112.

McManus, K.M., and J.S. Hanor. 1993. Diagenetic evidence for massive evaporite dissolution, fluid flow, and mass transfer in the Louisiana Gulf Coast. Geology 21: 727-730.

Meshri, I.D., and PJ. Ortoleva. 1990. Prediction of reservoir quality through chemical modeling, AAPG Memoir, 49, 175. Tulsa, Okla: American Association of Petroleum Geologists.

Milliken, M.L. 2005. Late Diagenesis and mass transfer in sandstone-shale sequences. In Sediments, Diagenesis, and sedimentary rocks. Treatise on geochemistry, ed. F.T. Mackenzie, vol. 7, 159-190. Oxford, UK: Elsevier.

Mohriak, W., M. Nemčok, and G. Enciso. 2008. South Atlantic divergent margin evolution: Rift-border uplift and salt tectonics in the basins of SE Brazil. Geological Society, London, Special Publications 294: 365-398.

Morad, S. 1998. Carbonate cementation in sandstones: Distribution patterns and geochemical evolution. In Carbonate cementation in sandstones. IAS special publication 26, ed. S. Morad, 1-26. Oxford: Blackwell Scientific Publications.

Moraes, M.A. 1989. Diagenetic evolution of cretaceous-tertiary turbidite reservoirs, Campos Basin, Brazil. AAPG Bulletin 73: 598-612.

Narasimhan, T.N., and P.A. Witherspoon. 1976. An integrated finite difference method for analyzing fluid flow in porous media. Water Resources Research 12: 57-64.

Parkhurst, D.L. 1995. User's guide to PHREEQC: A computer program for speciation, reaction-path, advective-transport, and inverse geochemical calculations, Water-Resources Investigations Report 95-4227, 143. Lakewood, CO, U.S: Geological Survey.

Parkhurst, D.L., and C.A.J. Appelo. 1999. User's guide to PHREEQC (Version 2): A computer program for speciation, batch-reaction, one-dimensional transport, and inverse geochemical calculations, Water-Resources Investigations Report 99-4259, 312. Reston, VA, U.S: Geological Survey.

Parkhurst, D.L., and C.A.J. Appelo. 2013. Description of input and examples for PHREEQC version 3: A computer program for speciation, batch-reaction, onedimensional transport, and inverse geochemical calculations, Techniques and Methods, 6-A43, 497. Reston, VA, US: Geological Survey.

Posey, H.H., and J.R. Kyle. 1988. Fluid-rock interactions in the salt dome environment: An introduction and review. Chemical Geology 74: 1-24.

Pruess, K. 1991. TOUGH2: A general-purpose numerical simulator for multiphase fluid and heat flow, 102. Berekeley, California: Lawrence Berkeley Lab.

Ranganathan, V., and J.S. Hanor. 1988. Density-driven groundwater flow near salt domes. Chemical Geology 74: 173-188.

Saenz, C.T., P.C. Hackspacher, J.H. Neto, P.J. lunes, S. Guedes, L.F.B. Ribeiro, and S.R. Paulo. 2003. Recognition of cretaceous, Paleocene, and Neogene tectonic reactivation through apatite fission-track analysis in Precambrian areas of Southeast Brazil: Association with the opening of the South Atlantic Ocean. Journal of South American Earth Sciences 15: 765-774.

Sarkar, A., J.A. Nunn, and J.S. Hanor. 1995. Free thermohaline convection beneath allochthonous salt sheets: An agent for salt dissolution and fluid flow in Gulf Coast sediments. Journal of Geophysical Research: Solid Earth 100 (B9): 18085-18092.

Sharp, J.M., Jr., T.R. Fenstemaker, C.T. Simmons, T.E. McKenna, and J.K. Dickinson. 2001. Potential salinity-driven free convection in a shale-rich sedimentary basin: Example from the Gulf of Mexico basin in South Texas. AAPG Bulletin 85: 2089-2110

Stumm, W., and J.J. Morgan. 2012. Aquatic chemistry: Chemical equilibria and rates in natural waters (Vol. 126), 1040. John Wiley \& Sons.

Taylor, T.R., M.R. Giles, L.A. Hathon, T.N. Diggs, N.R. Braunsdorf, G.V. Birbiglia, M.G. Kittridge, C.I. Macaulay, and I.S. Espejo. 2010. Sandstone diagenesis and reservoir quality prediction: Models, myths, and reality. AAPG Bulletin 94: 1093-1132.

Teixeira, W.S., and M.G.C. Vincentelli. 2017. Geophysical characterization of exploratory plays in the central portion of Espirito Santo Basin. In 15th International Congress of the Brazilian Geophysical Society \& EXPOGEF, Rio de Janeiro, Brazil, 453-458.

Tempel, R.N., and W.J. Harrison. 2000. Simulation of burial diagenesis in the Eocene Wilcox Group of the Gulf of Mexico Basin. Applied Geochemistry 15: 1071-1083.

van Bennekom, A.J., J.F. Jansen, S.J. van der Gaast, J.M. van Iperen, and J. Pieters, 1989. Aluminium-rich opal: An intermediate in the preservation of biogenic silica in the Zaire (Congo) deep-sea fan. Deep Sea Research Part A. Oceanographic Research Papers 36: 173-190. 
Worden, R.H., and S.D. Burley. 2003. Sandstone diagenesis: The evolution of sand to stone. In Sandstone Diagenesis: Recent and Ancient, eds. Stuart D. Burley and Richard H. Worden, Blackwell, pp. 1-44. https://www.scopus.com/record/ display.uri?eid=2-s2.0-84978020854\&origin=inward\&txGid=211 bf1 1 edd947e29 b1acf8ee622ca650

$\mathrm{Xu}, \mathrm{T}$. and K.Pruess. 1998. Coupled modeling of non-isothermal multiphase flow, solute transport and reactive chemistry in porous and fractured media: 1. Model development and validation. Lawrence Berkeley National Laboratory, Berkeley, California, 38.

Yang, L., T. Xu, K. Liu, B. Peng, Z. Yu, and X. Xu. 2017. Fluid-rock interactions during continuous diagenesis of sandstone reservoirs and their effects on reservoir porosity. Sedimentology 64: 1303-1321. http://homepage.ufp.pt/ biblioteca/HydrocarbonPotentiaOfllnfraSaltSedimentsAngola/Images/ Plate006.4-EspSantoOffs.jpg. Accessed 1 Sept. 2018.

\section{Submit your manuscript to a SpringerOpen ${ }^{\circ}$ journal and benefit from:}

- Convenient online submission

- Rigorous peer review

- Open access: articles freely available online

- High visibility within the field

- Retaining the copyright to your article

Submit your next manuscript at $\boldsymbol{\nabla}$ springeropen.com 